DOl: 10.19195/2353-8546.6.8

\author{
GABRIELA ABRASOWICZ*
}

Uniwersytet Wrocławski (Polska)

\title{
Dziecięce odgrywanie traumy we współczesnym teatrze serbskim
}

\begin{abstract}
Children's traumatic enactment in contemporary Serbian theatre. The problem of traumatic codes in post-Yugoslav theater is increasingly attracting attention of many researches. Dramas written by Serbian authors: Biljana Srbljanović, Milan Marković and Tanja Šljivar depict the historical background and tragedies from children's point of view. The youngest citizens, the voices of the traumatized culture, participate in the process of re-enacting incriminating events through (in)offensive plays and games.

This article considers idiosyncrasies of representation of trauma in Serbian theater and drama through the construction of figures of children, victims and witnesses, who intensify the tragedy, but also get the recipients thinking about the possibilities of working through the trauma and adapting to the new post-war and post-transition reality. This phenomenon is particularly reflected in dramas Family Stories (B. Srbljanović), Maya and Me and Maya (M. Marković), Scratching or How My Grandmother Killed Herself (T. Šljivar).
\end{abstract}

Keywords: children's perspective, elements of children's play, Serbian contemporary theater, trauma, violence

Детское исполнение роли травматизма в современном сербском театре. Вопрос травматических кодов, представленных в пост-югославском театре все больше привлекает к себе внимание многих исследователей. Драмы, написанные сербскими авторами: Бильяной Срблянович, Миланом Марковичем и Таней Шлийвар представляют исторические предпосылки видения трагедии, представленной с точки зрения детей. Самые молодые граждане - конкретные голоса травматической культуры - участвуют в воспоминаниях о трагических событиях во время (не) винных игр.

В статье содержатся соображения по поводу специфического способа представления травмы в сербской драме и театре путем представления персонажей детей - жертв и свидетелей - которые не только усиливают чувство трагедии, но, как правило, заставляют задуматься

* Adres do korespondencji: ul. Łączności 11/40, 53-330 Wrocław. E-mail: fuchschen@wp.pl. 
о возможностях работы над травмой и адаптироваться к новой реальности после войны и к изменениям. Эта специфика находит свое отражение в анализируемых текстах: Семейные ситуации (Б. Срблянович), Мая и я и Мая (М. Маркович), Царапание или Как умерла моя бабушка (Т. Шлийвар).

Ключевые слова: детская перспектива, насилие, сербский современный театр, травма, элементы детской игры

Artyści z krajów byłej Jugosławii poświęcili wiele uwagi doświadczeniom traumatycznym związanym z krytycznymi momentami ostatniego dwudziestolecia (takimi jak działania zbrojne, etniczne napięcia, rozbicie państwa, okres tranzycji) i ich oddziaływaniom na bieżące życie ofiar oraz świadków. Przetwarzając wyobrażenia skrajnych przeżyć emocjonalnych i urazów wywołujących specyficzny oddźwięk, twórcy nie pomijają kwestii dotyczących modeli upamiętniania, a także, charakterystycznych dla pokrzywdzonych, reakcji oraz procesów adaptacyjnych. Wprowadzanie treści dotyczących traumatycznego wymiaru wydarzeń przełomowych dla konkretnych grup do sztuki postjugosłowiańskiej może być traktowane jako nieodłączny element (g)lokalnej, zrutynizowanej nieco, „kultury rany”, czyli fenomenu wykorzystania w definiowaniu tożsamości postrzępionych wspomnień odnoszących się do granicznych sytuacji i negatywnych przeżyćl .

Wśród badaczy wzrasta zainteresowanie kłopotem z przekazaniem wiedzy traumatycznej ${ }^{2}$ oraz inflacją pojęcia traumy i nadużywaniem go w wielu współczesnych dyskursach. Przytłaczające doświadczenie, które często opiera się możliwości scalenia i wyrażenia, wykracza poniekąd poza język, który zawodzi w jego obliczu i jest niewystarczający ${ }^{3}$. Dominujący pogląd, że trauma jest niewypowiadalna i nie podlega reprezentacji ${ }^{4}$, zostaje przełamany przez dramatopisarzy oraz realizatorów spektakli teatralnych, którzy w swych propozycjach zachowują kształt traumatycznego doświadczenia i nie redukują jego znaczenia. Twórcy aktywni w Serbii konsekwentnie dążą do wypracowania języka opisu tego zjawiska i wynalezienia nowych idiomów, które pozwalałyby o nim opowiedzieć ${ }^{5}$. Przede wszystkim dzięki temu, iż „teatr bardziej niż tekstualna nierozstrzygalność i nieczytelność umożliwia uzyskanie dostępu do traumy"6 udaje się im wyznaczyć przekonujące ramy klasyfikacji kul-

1 Por. M. Seltzer, Kultura rany, tłum. A. Rejniak-Majewska, [w:] Antologia studiów nad traumą, red. T. Łysak, Kraków 2015, s. 313-358.

2 G.H. Hartman, Wiedza traumatyczna i badania literackie, tłum. J. Burzyński, [w:] Antologia..., s. 408.

${ }^{3}$ L. Gilmore, Przypadki graniczne: trauma, autoprezentacja i prawne formy tożsamości, tłum. J. Burzyński, [w:] Antologia..., s. 365.

4 Ibidem.

5 A. Lowenstein, Moment alegoryczny, tłum. J. Burzyński, [w:] Antologia..., s. 290.

6 S. Craps, Poza eurocentryzm. Teoria traumy w epoce globalizacji, tłum. J. Burzyński, [w:] Antologia..., s. 418. 
turowej $^{7}$. Ich osobliwe, zaangażowane projekty wpisujące się w nurt produkcji traumatofilnej (czyli np. utworów napisanych w duchu „traumy apatii” lub „dramatu wojennej traumy"9) stanowią konstrukty pamięci, które pozwalają wyrazić problem rozziewu między doświadczeniem i jego rozumieniem oraz w sposób przemyślany ujmować tę „wielowymiarową ranę" w formę słów, dźwięku, obrazów i ruchu.

Nowoczesna postjugosłowiańska, w tym serbska, produkcja dramatopisarska i sceniczna czerpie w zasadzie bez ograniczeń z kapitału kulturowego, jakim jest wielopoziomowa trauma oraz jej echa. Twórczość ta zawłaszcza bolesne wydarzenia i udostępnia coraz bardziej trafne płaszczyzny ich postrzegania. Na tle utworów, w których trauma stała się poręcznym, a czasem wręcz niezbędnym narzędziem opisu rzeczywistości uchwyconej w dobie intensywnych przemian, na uwagę zasługują, nieliczne wciąż, teksty dramatyczne konstruowane na podstawie kolektywnego dziecięcego głosu ${ }^{10}$. Strategię taką przyjęli m.in. Biljana Srbljanović, Milan Marković i Tanja Šljivar. Kody traumatyczne korespondują w ich propozycjach artystycznych $\mathrm{z}$ ujęciem grup dzieci jako zasobu kontrwiedzy lokowanego na marginesach społeczeństwa, a także opisem przemieszczenia lub rzucenia w stan niepewności tożsamości jej członków. W tych konkretnych przypadkach ekspozycja nieco innego kulturowego poziomu zbiorowości w szczególny sposób odzwierciedla destrukcyjny wpływ dziejowych perturbacji na kondycję organizmu społecznego ${ }^{11}$.

Analiza tekstów Sytuacje rodzinne (1998) Biljany Srbljanović, Maja i ja i Maja (2012) Milana Markovicia i Drapanie albo Jak zabiła się moja babcia (2012) Tanji Šljivar wskazuje na podobieństwa pod względem ich poetyki, choć brak tu biograficznych punktów wspólnych czy istotnych zbieżności twórczych debiutów autorów ${ }^{12}$.

7 T. Łysak, Trauma - od genealogii pojęcia do studiów nad trauma, [w:] Antologia..., s. 16.

${ }^{8}$ N. Govedić, Trauma apatije: dvije dramatičarske postjugoslavenske Nigdine (Ivana Sajko i Biljana. Srbljanović), [w:] Dramski tekst danas u Bosni i Hercegovini, Hrvatskoj, Srbiji i Crnoj Gori (Medunarodni simpozijum univerzitetskih predavača, teatrologa i pozorišnih kritičara), red. S. Anđelković, Novi Sad 2004, s. 152-166.

9 D. Lukić, Drama ratne traume, Zagreb 2009.

10 Włączanie postaci i głosów dzieci do utworów dramatycznych nie stanowi novum. Dotychczas postać dziecka zyskiwała prawo obywatelstwa nadawane przez współczesnych autorów z terenów byłej Jugosławii, opracowujących temat traumy, jednak w przeważającej mierze pełniła ona funkcję uzupełniającą. „Odgrywanie w działaniu” grup dzieci pojawia się natomiast rzadziej i jest to niewątpliwie jedna $\mathrm{z}$ bardziej odkrywczych oraz ciekawych dróg prowadzących do pełniejszego przedstawienia wiedzy o zarejestrowanym zdarzeniu traumatycznym i wspomnienia o nim.

11 P. Długosz, Strategie radzenia sobie z trauma przemian na Podkarpaciu, [w:] Oblicza europejskiego pluralizmu, red. Z. Drozdowicz, Poznań 2003, s. 205.

12 Warto prześledzić aktywność tych twórców, a konkretnie porównać dane (z dalszej części tekstu), w jakich momentach swojego życia i w jakich punktach zwrotnych historii ich kraju powstały przywołane tu dramaty. Należy odnotować, że w wypadku zbliżonych postaw autorów analizowanych tu tekstów zauważalne są pewne przesunięcia z pozycji zewnętrznego obserwatora (dorosła już w latach dziewięćdziesiątych B. Srbljanović), współuczestnika (wychowany na serii „Maja” M. Marković), aż do wszczepiania wątków autobiograficznych (odwołania do własnego dzieciństwa T. Šljivar). Poza tym zmienia się też sposób i poziom autorskiego zaangażowania: B. Srbljanović zwiastuje i alarmuje, wskazując szkodliwość przemian ostatniej dekady XX wieku, podczas gdy dramat autorstwa Markovicia jest 
Warto zastanowić się, jakimi kryteriami kierowali się dramatopisarze przy doborze odpowiednich sposobów artystycznej artykulacji sprzężonej z dziecięcą perspektywą i konwencją gry-zabawy, jakie intencje przyświecały kreowaniu alternatywnych prawdopodobnych dziecięcych światów przesyconych przemocą oraz jakie efekty osiągają twórcy tych projektów. Krótka charakterystyka tekstów „o dzieciach, ale nie dla dzieci” pozwoli zapewne przybliżyć się do odpowiedzi na powyższe pytania.

\section{Zabawy w dorosłość}

W Sytuacjach rodzinnych ${ }^{13}$ (Porodične priče ${ }^{14}, 1998$ ), podobnie jak w pozostałych utworach Biljany Srbljanović ${ }^{15}$ (ur. 1970, Sztokholm), nakreślony został świat jawnej agresji oraz biernego oporu kiełkujących w atmosferze postępującego rozkładu i atrofii komunikacji. Bezkompromisowa autorka wykorzystuje zabawy i „dziecięcą fantazję jako szkło powiększające, przez które dostrzegamy surowość życia, jakiej dorośli zupełnie nie odczuwają" ${ }^{36}$.

W odgrywanych sytuacjach ostrze autorskiej krytyki dosięga fundamentu życia społecznego, czyli rodziny. Przeprowadzając jej wiwisekcję, dramatopisarka dekonstruuje oraz krytykuje role społeczne kultywowane w cieniu patriarchatu i opresji. Vojin, Milena i Andrija bawią się w dom na śmietniku jednego z belgradzkich osiedli, wiernie naśladując swoich rodziców, reinscenizując wycinki z codziennego życia zbudowanego z negatywnych klisz społecznych. Obserwująca ich Nadeżda, która dla potrzeb zabawy stara się dostosować do obowiązujących standardów i posługuje się nawet niemym „psim” językiem, nie zostaje zaakceptowana, a jej „Inność” spotyka się z niepohamowanym okrucieństwem.

Skrzywdzone dzieci wielokrotnie uśmiercają swoich rodziców, jakby wierzyły, że żywioł przemocy raz puszczony w ruch nie da o sobie zapomnieć. W ich odczuciu dorosłych nie można zmusić do zmiany torów myślenia i działania, dlatego muszą oni zostać unicestwieni. Wszystkie podwórkowe zabawy kończą się katastrofalnie

próbą eksplikacji i zrozumienia, na jakie próby wystawiona została młodzież dorastająca w momencie rozpadu Jugosławii, T. Šljivar — najmłodsza z autorów — dokonuje zaś pewnego obrachunku, prezentując jednocześnie skutki wieloaspektowej deprywacji dzieci.

13 B. Srbljanović, Sytuacje rodzinne, tłum. D.J. Ćirlić, „Dialog” 1999, nr 5. Dalej cytuję według tego wydania, podając w nawiasie numery stron w tekście zasadniczym. Premiera teatralna: Atelje 212, 1998, reż. J. Marković. Sztuka ta wzbudziła ogromne zainteresowanie polskich reżyserów i doczekała się aż siedmiu premier, z których pierwsza miała miejsce w 2000 roku (Wrocławski Teatr Współczesny im. E. Wiercińskiego, reż. K. Meissner).

14 B. Srbljanović, Porodične priče, [w:] eadem, Pad - Beogradska trilogija - Porodične priče, Beograd 2000.

15 Jedna z najbardziej znanych serbskich autorek, współpracuje z wieloma europejskimi artystami. Zaangażowana politycznie i społecznie wykładowczyni na Wydziale Sztuk Dramatycznych w Belgradzie oraz uznana jurorka w prestiżowych konkursach dramatopisarskich.

16 M. Lazin, Otkud uspeh Biljane Srbljanović?, [w:] Dramski tekst..., s. 172. 
dla kreowanych postaci ojca i matki, którzy po unieszkodliwieniu ożywają oraz uwalniają pewien ładunek ironicznego wampiryzmu.

Warto zaznaczyć, że młodzi bawią się bez nadzoru osób dorosłych, co może skłaniać do formułowania wniosku, że rodzice bohaterów faktycznie zginęli i podczas tych (nie)winnych gier zostają wskrzeszeni jedynie przez cytowane kwestie. Zamknięte, odizolowane podwórko może zatem funkcjonować jako miejsce podobne do piekła, w którym karą jest niekończące się odtwarzanie i przeżywanie zbrodni. Z drugiej strony (zgodnie ze wskazówką autorki), postaci dzieci odgrywane są przez dorosłych aktorów, co można odczytać jako sugestię, że przedstawicieli generacji „ojców” należy utożsamiać z osobami niedojrzałymi i niezdolnymi do ponoszenia odpowiedzialności.

Dramatopisarka prezentuje instynktowną ucieczkę w sekwencję zabaw w dom, obfitujących w kompulsywne nadużycia, które wskazują na nieprzełamaną jeszcze apatię oraz totalną niemożność artykułowania uczuć. Srbljanović demonstruje np. dziecięce rozumienie seksualności jako stanowiska oznaczającego całkowity brak intymności i uwzględniania odczuć drugiego człowieka. W rezultacie tego dostępne ciało Nadeżdy staje się użytecznym, łatwym w obsłudze narzędziem zapewniającym rozładowanie energii. Dzieci odtwarzają ten akt na podstawie strzępków informacji i zniekształconych wyobrażeń:

Dziesięcioletni Andrija onanizuje się pod brudnym kocem, śpiewając czetnicką pieśń, której słów nie zna.

Czując podniecenie, którego przyczyny także nie zna, masturbuje się coraz szybciej.

Nadeżda nagle drży, po czym zwinnie wsuwa się pod koc.

Andrija, wykrzykując melodię, energicznie kładzie się na Nadeżdzie. Przez kilka następnych chwil, w kurczowym zwarciu, przy okrzykach bólu i intuicyjnej rozkoszy, Nadeżda i Andrija przetaczają się po scenie. Sprawiaja wrażenie, jakby się bili albo kochali.

Nadeżda nagle krzyczy, Andrija wydaje z siebie głośne westchnienie. Oboje uspokajaja się, jakby odrętwiali. Nadeżda zsuwa się z Andrii, kładzie obok niego. Milcza [...] Andrija cicho pyta

ANDRIJA: Jak masz na imię?

Nadeżda waha się, po chwili szepcze mu swoje imię do ucha.

Andrija nagle podnosi się, zaczyna skakać wokół Nadeżdy i krzyczeć na melodię tej samej czetnickiej pieśni.

ANDRIJA: Pieprzyłem Nadeżdę! Pieprzyłem Nadeżdę! (s. 58)

W zamykającym tekst monologu Nadeżda wyznaje, że wysadziła w powietrze swoich rodziców. Stało się to przez przypadkowo znalezioną i potraktowaną jak zabawkę bombę ojca. Czyn ten zostaje zaprezentowany innym dzieciom na podwórku jako rekonstrukcja nieumyślnej zbrodni. Postać początkowo niemej i stopniowo aktywizującej się dziewczynki funkcjonuje niczym klamra spinająca dramat, można też uznać, że sytuacje rodzinne opowiedziane zostały właśnie z jej perspektywy, że to sceny z jej życia.

NADEŽDA: Mamo, obudź się, proszę cię, tato, tatusiu, przepraszam, nie chciałam, naprawdę nie chciałam, już nigdy nie będę... z brudnymi rękami do stołu, robić kleksów na książkach, rozrzucać ga- 
zet, wykrzykiwać haseł, żądać pieniędzy, płakać, kiedy się uderzę, drzeć pończoch, zakochiwać się, pluć do zupy, kraść pieniędzy z portmonetki, rozbijać kolan, chcieć słodyczy, ściągać w szkole, rozmawiać o polityce, czuć wstrętu, kiedy tacie się odbija, domagać się posagu, pomocy, mieszkania, planować przyszłość, pragnąć własnego życia, mieć swojego zdania, opowiadać się za postępem, szczęściem i pokojem, dorastać, wychodzić za mąż i mieć dzieci! (s. 69)

Nadeżda spowiada się ze swoich grzechów, a lista ta stanowi wstrząsający inwentarz przejawów ograniczenia i łamania praw dziecka — prawa do rozwoju, wolności słowa, miłości rodzicielskiej i szacunku, opieki, a nawet elementarnego prawa do życia. Jest to zarazem diagnoza i zwiastun patologizacji podmiotowości społecznej.

\section{Koniec bajkowego dzieciństwa}

Dramat Maja i ja i Maja ${ }^{17}$ (2012) Milana Markovicia ${ }^{18}$ (ur. 1978, Belgrad) stanowi kompilację rodzimej i zachodnioeuropejskiej koncepcji artystycznej. Powstał na motywach popularnych w byłej Jugosławii książeczek dla dzieci „Martine” autorstwa Belgów - Gilberta Delahaye’a i Marcela Marliera — oraz powieści serbskiego pisarza Sretena Ugričicia. Główna bohaterka kultowej ilustrowanej serii zapoczątkowanej w 1954 roku — Martynka — mieszkała w Brukseli i mogła cieszyć się szczęśliwym, godnym pozazdroszczenia dzieciństwem. W wersji wydawanej w Belgradzie oraz Zagrzebiu postać ta zmieniła imię i jako Maja zostawiła trwały pozytywny ślad w wyobraźni pokoleń, które dorastały na obszarze dawnej Jugosławii. Opowieści te były ciepłymi i zabawnymi tekstami, znakomicie uzupełnionymi piękną oprawą graficzną oraz uchodziły za zbiór o bezsprzecznych walorach edukacyjnych. Książka Ugričicia Maja i ja i Maja. Powieść o dorastaniu (Roman o odrastanju) z 1993 roku opowiada $\mathrm{z}$ kolei o rozpadzie Jugosławii i politycznych transformacjach w Europie z perspektywy Mai oraz prezentuje, jak wpływają one na beztroskie dotąd życie dziewczynki.

W niecodziennych zabawach z bratem Miszą bohaterka zaczyna sprawdzać granice wytrzymałości swojego ciała oraz wykazuje tendencje, by komunikując się z otoczeniem, zadawać sobie i innym ból. Przejawia się to zarówno w kontaktach z grupą rówieśniczą, jak i z dorosłymi.

17 M. Marković, Maja i ja i Maja. Utwór dostępny w wersji elektronicznej w otwartym archiwum na portalu „Nova drama”, 9 września 2016, https://docs.google.com/document/d/1LFtYf4rqtBl-hRNGGZrGtPn1Rd86bB1MGK8TkQzM3GU/edit. Dalej cytuję według tego tekstu w przekładzie własnym. Premiera teatralna: Bitef Teatar, 2012, reż. A. Suša. Spektakl gościł dwukrotnie w Polsce w 2014 roku: w ramach Światowego Kongresu „Assitej” (Warszawa) oraz Międzynarodowego Festiwalu Teatralnego „Demoludy” (Olsztyn, tłum. G. Abrasowicz).

18 Milan Marković był w latach 2007-2010 koordynatorem projektu „Nova drama”. Autor na długo związany z szeroko rozumianą produkcją teatralną w Belgradzie, współpracował jednocześnie z chorwackimi, słoweńskimi i duńskimi artystami. Obecnie mieszka i pracuje w Szwecji. 


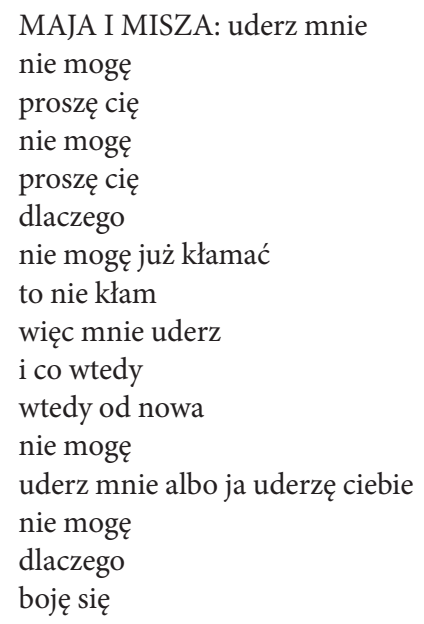

W dramacie serbskiego autora bajka zamienia się w koszmar i roztrzaskuje o asfalt kondensującej się rzeczywistości - Maja zabija rodziców i zostaje wychowanką domu poprawczego. Próbując walczyć o swoją wolność i odcięcie się od niegościnnego zastanego świata, decyduje się na zachowania ryzykowne i nieaprobowane lub izolację przez sentymentalne podróże oraz wejście w bezpieczne strefy przesycone atmosferą bajkowości.

Projekt o Mai bada postjugosłowiańskie dziedzictwo i możliwość realizowania się pomimo braku socjopolitycznej ciągłości. Milan Marković przesuwa punkt uwagi z samego zdarzenia na jego przedstawienie, a pojęcie traumy wydaje się odpowiadać destrukcyjnej definicji podmiotu, który zrywa z linearną przyczynowością i uwarunkowaniem oraz nieustannie „sam siebie podważa" ${ }^{19}$.

W dramacie o najbardziej bolesnych toposach problematyzowanych w kontekście współczesnych osobistych i społecznych ram pamięci bohaterka obserwuje świat zmierzający w jej przeświadczeniu ku upadkowi i postanawia coś zmienić, wpłynąć na losy swoje i innych. Maja kumuluje w sobie cechy reprezentantów pokolenia, w którym pokładano ogromne nadzieje, jednak pokolenia straconego. Dziewczynka uzewnętrznia powszechną potrzebę wskazania winowajców i domaga się zadośćuczynienia:

MAJA: Czasami wydaje mi się, że ten świat jest za duży

A czasami wydaje mi się, że jest zbyt mały

Kiedy mocno zacisnę ręce i zamknę oczy

Widzę kręgi płomieni, pragnę zapalić świat

I zemścić się na nich

Za co

Za wszystko

19 M. Seltzer, op. cit., s. 327. 
Serbski dramatopisarz, przez zestawienie różnych punktów obserwacyjnych i sposobów kontekstualizacji, ilustruje zderzenie odmiennych poziomów, porządków i światów. Prawdziwa Maja-Belgijka osadzona była w lepszej, alternatywnej rzeczywistości, nieosiągalnej dla belgradzkiej Mai. Ten rozdźwięk jest cały czas odczuwalny. Serbskie Everychild końca XX wieku boryka się z problemem ustosunkowania się do wątpliwej wartości dziedzictwa, otwartych symbolicznych ran oraz niewyrażalnej utraty czy nawet nieobecności. Wizja Milana Markovicia skłania też do refleksji nad wybitnie traumatogenną mocą czarnej pedagogiki i deprywacji potrzeb wplecionych w chaos okresu wojny oraz tranzycji. Sytuacja dziecka, które, chcąc oddać emocje przekraczające jego zdolności rozumienia, pozostaje uwięzione w kręgu cytowanych pasywnych reakcji, jest właśnie tego pokłosiem.

\section{Rozdrapywanie ran}

Praca dyplomowa młodej dramatopisarki Tanji Šljivar ${ }^{20}$ (ur. 1988, Banja Luka) stanowi próbę opisania surowej rzeczywistości lat dziewięćdziesiątych oraz jej oddziaływania na proces dorastania dzieci, wraz z efektami ubocznymi. Akcja dramatu Drapanie albo Jak zabiła się moja babcia (Grebanje ili Kako se ubila moja baka ${ }^{21}$, 2012) rozgrywa się w 2000 roku w Banja Luce, zanim w burzliwym okresie przebudowy systemu wygasła nadzieja, że przyszłość przyniesie dobrobyt i stabilizację. Dowiadujemy się również o wydarzeniach, do których dochodzi później we Frankfurcie, kiedy główna bohaterka - Maja - sprzedaje nagrania video z udziałem swoim i swoich kolegów.

Utwór o dotkliwym odczuwaniu przemian Šljivar rozpisała na głosy dziesięciolatków, którzy przygotowują się do szkolnej imprezy charytatywnej w sali gimnastycznej, nie wiedząc, że w tego typu pomieszczeniach organizowano w czasie akcji zbrojnych na terenie Bośni sale tortur oraz tymczasowe obozy koncentracyjne. Działania dzieci mają teoretycznie polepszyć jakość życia niepełnosprawnego, poruszającego się na wózku inwalidzkim ucznia Kosty — na co dzień gnębionego „chłopca do bicia”. Autorka stosuje manewry mające na celu odsunięcie się od głównego wątku na rzecz słodko-gorzkich wspomnień o dorastaniu w minionej dekadzie. Wplata także wielokrotnie w tkankę utworu sceny związane z samobójstwem babci Mai, która

20 Autorka urodzona w Bośni i Hercegowinie jest absolwentką dramaturgii na Wydziale Sztuk Dramatycznych w Belgradzie. Współpracuje z serbskimi dramaturgami i realizatorami scenicznymi. Doskonaliła swoje umiejętności na Justus-Liebig-Universität w Giessen.

21 T. Šljivar, Grebanje ili Kako se ubila moja baka, [w:] Biseri iz upravničkih fioka, red. S. Bodroža, Beograd 2013. Dalej cytuję według tego wydania, podając w nawiasie numery stron w tekście zasadniczym. Premiera teatralna: „BNP Zenica” w kooperacji z Teatrem „Bitef” i Fundacją „Hartefakt” 2012, reż. S. Spahić. Dla potrzeb czytania performatywnego realizowanego podczas IX edycji Międzynarodowego Festiwalu Teatralnego „Demoludy” (Olsztyn, 2015) powstał przekład tekstu na język polski (tłum. G. Abrasowicz, B. Nikodemska). 
staje się idolką, wzorem kobiety nieskrępowanej i uwolnionej spod jarzma surowej rzeczywistości.

MAJA: Kiedy babcia była młoda, jeździła starym wartburgiem jak szalona. Raz urwał jej się film, wsiadła do auta i wzięła flaszkę rakii. Kiedy tak pędziła, myślała o Marze. Mara nauczyła ją golić nogi tak, żeby się nie zaciąć. Opuściła szybę i wystawiła głowę. Wiał wiatr, włosy wpadły jej do ust. Zamknęła oczy, bo nie chciała, aby mur był ostatnią rzeczą, jaką widzi, i krzyczała. Rozbiła się i flaszka, i szyba, i przednie światła, i czaszka babci. Kiedy ją znaleźli, pachniała rakiją i benzyną. (s. 303)

Postać dziewczynki ukazana jest w odniesieniu do grupy towarzyszy oraz po przeprowadzce, kiedy próbuje utrzymać trudną przyjaźń z „Małą Niemką, która kiedyś była Serbką". Dowiadujemy się, że mimo wtopienia się Mai w „gorszą" kulturę dzikiej i prymitywnej Bośni, otrzymała ona szansę na nowe, dostatnie i cywilizowane, życie na Zachodzie. Nie potrafi jednak i nie chce rozstać się z, w dużej mierze, bolesną przeszłością. Maja wierzy, że ciało zawsze będzie pamiętać, dlatego prowokuje do wzajemnego naznaczania i okaleczenia skóry swych towarzyszy zabaw, połączonego z namiastkami inicjacji seksualnej. Rany pozwolą jej zdaniem umocnić pamięć zbiorową, która wyrosła ze wspólnych osobistych doświadczeń i pragnień artykułowanych uzgodnionym symbolicznym językiem:

Maja bierze rękę Đorđa.

MAJA: Twoja skóra jest cienka i blada. Widać każdą żyłę. Nie będziesz wiedział, że jest naprawdę twoja, dopóki cię nie zaboli.

Maja drapie rękę Đorđa.

MAJA: Kiedy wbiję i przeciągnę, i wygrzebię, będzie ciepławe i czerwone, i słone. Jeśli wytrzymasz minutę, nie jesteś pedał. Jeśli wytrzymasz minutę, znowu ci pokażę, że nie mam cycków. Jeśli wytrzymasz minutę, ty też mnie podrapiesz.

Kiedy wrócę, chcę cię po tych ranach rozpoznać. Tu nie może cię dotknąć żadna inna dziewczyna. Tu tylko mama może przyłożyć ci okład z rakii. Tu ja drapałam i teraz będę lizać. (s. 301)

Młodzi bohaterowie nawet podczas zabaw są okrutni i rozhamowani. Serbski dramaturg Filip Vujošević zauważył, że tekst ten „w sposób bezpośredni i brutalny odnosi się do doświadczania bólu i narastającej patologii wśród dzieci, jako następstwa manipulacji ze strony rodziców, nauczycieli, nacjonalistycznego środowiska, w którym dorastali”22. Przemoc, która jest wynikiem niespełnionych pragnień, braku relacji z rodzicami, niezdolności do wyrażania uczuć, ewoluuje w dramacie od stadium drapania swojego i cudzego ciała, poprzez strzelanie z broni, do sadystycznego znęcania się nad najsłabszymi. Tanja Šljivar rozwija w tym kontekście historię o odejściu i utracie, o pokoleniu, które cierpiało, dojrzewając w systemie pozbawionym prawdziwych wartości, lecz przesiąkniętym zakazami i nakazami ${ }^{23}$.

22 F. Vujošević, Riječ dramaturga, 9 września 2016, http://www.bnp.ba/bnp/predstave/velikascena/grebanje.

${ }^{23}$ Należy nadmienić, że T. Šljivar w swej najnowszej, opartej na faktach, propozycji Tak jak wszystkie wolne dziewczyny (Kao i sve slobodne djevojke) również decyduje się na uwydatnienie punktu widzenia dzieci (tym razem $\mathrm{z}$ wypowiedzi grupy dziewczynek utkany jest krytyczny komentarz 


\section{Odgrywanie „anormalnej normalności"24 traumy a współgranie z oczekiwaniami odbiorców}

Pogłębiona analiza porównawcza prezentowanych utworów pozwala dostrzec zazębiające się pola oraz wyróżnić wiele cech wspólnych. Wyprowadzony na tej podstawie wzór zawiera takie elementy, jak: dominacja postaci dzieci funkcjonujących jako ogniwa w łańcuchu traumatycznych powtórzeń, ukazanie relacji przemocowych oraz działań (auto)destrukcyjnych, a przede wszystkim zastosowanie konwencji dziecięcej zabawy jako translokacji i reaktywacji traumy. Srbljanović, Marković i Šljivar przez pryzmat niestandardowych gier przedstawiają trudne do przyjęcia dziedzictwo, na którym widnieją krwawe ślady z przeszłości, oraz demaskują maniakalne ukrywanie się za chybotliwą konstrukcją niezdefiniowanej przyszłości. Autorom udało się uniknąć infantylizacji i banalizacji „małych historii o małych ludziach"25. Wprost przeciwnie, kod ten okazuje się niezwykle pojemny i adekwatny z następujących względów.

Przede wszystkim, egzemplifikacja procesów odgrywania traumy podczas spotkań dzieci gwarantuje sugestywny przekaz wywołujący skrajne reakcje odbiorców. Obraz młodego pokolenia, w którym przeglądają się dzisiejsi dorośli, wzmaga niezaprzeczalnie tragizm utworów i jeszcze bardziej aktualizuje twierdzenie, że trauma wykracza poza zwyczajowe normy i oczekiwania, a w związku z tym doświadczenie to nigdy nie staje się częścią zwykłego systemu pamięci ${ }^{26}$. Dzieci - szczególnie wrażliwi i podatni na wpływy „Inni” - to baczni obserwatorzy przemian oraz przymusowi użytkownicy systemu zaprojektowanego przez starsze pokolenia, a ich sposób bycia wskazuje, niczym papierek lakmusowy, wszelkie społeczne dysfunkcje. Ponadto, autorzy odwołują się do tezy, że wydarzenia stresogenne z wczesnego okresu życia mogą odbijać się ujemnie na wszystkich wymiarach zdrowia w dalszych etapach rozwoju, co mogło zaowocować ich aktualnymi problemami $\mathrm{z}$ adaptacją do dynamicznej rzeczywistości i kłopotliwej spuścizny ${ }^{27}$.

W tekstach dramatycznych wskazane jest także ewentualne ryzyko, że przepracowanie przeszłości i krzywd przedstawicieli generacji dorastającej na przełomie tysiącleci zostało przedwcześnie przerwane oraz niemożliwe do realizacji. Dostępny dzieciom sposób widzenia rzeczywistości zostaje bowiem zbyt szybko „zakłócony” treściami i wyobrażeniami, które wprowadza pamięć kultury oraz dziedziczenie niewłaściwych postaw. Bohater, który dopiero dojrzewa, wkracza w świat zabaw

dotyczący fatalnego poziomu edukacji seksualnej oraz zakłamanej moralności, tak powszechnych, zdaniem autorki, w Bośni i Hercegowinie).

${ }^{24}$ M. Seltzer, op. cit., s. 316.

25 Por. D. Nikolić, Deca autizma ili Male priče o malim ljudima, [w:] Dramski tekst..., s. 141-151.

26 T. Łysak, op. cit., s. 20.

27 Jest to dostrzegalne w tekstach autorstwa M. Markovicia i T. Šljivar stanowiących komentarze post factum, natomiast w wypadku dramatu B. Srbljanović można dopatrywać się pewnej faktograficzno-prognostycznej analizy. 
opartych mocno na naśladownictwie z nadbagażem nie tylko zaburzających rozwój doświadczeń, lecz także wiedzy, zasobu leksykalnego i skryptów społecznych przyswojonych ze świata dorosłych. Skonfrontowany z obciążającymi negatywnymi zdarzeniami, zostaje niejako skazany na przedwczesną pseudodojrzałość sprzężoną z zaburzeniami kompetencji interpersonalnych i poczucia bezpieczeństwa, niemożnością zaspokojenia podstawowych potrzeb, doświadczaniem przemocy i demoralizacji ${ }^{28}$.

Z drugiej strony, obecne w utworach figury dzieci, choć obarczone niewygodnym dziedzictwem i narażone na sytuacje trudne, mogą służyć rozbudzeniu nadziei na doświadczanie pozytywnych zmian w posttraumatycznym rozwoju, a w rezultacie na przekształcenie i oswojenie narastającego chaosu. Skoro najmłodsi wykazują zdolność do przeprowadzenia tak skomplikowanej intelektualnej, emocjonalnej i językowej operacji, istnieje spore prawdopodobieństwo, że uda się to współczesnym dorosłym.

Poza tym, dzięki zabiegowi włączania dziecięcych głosów, odbiorca zostaje wyczulony na wsłuchiwanie się w głos „Innego"29, ponieważ młodzi bohaterowie szczególnie dobitnie podkreślają „negatywne uprzywilejowanie” grup marginalizowanych. Znajdują się oni w przestrzeni różnicy i podporządkowania, lecz zostają wezwani przez dramatopisarzy do tego, by dawać świadectwo prawdzie o powiązaniach jednostki i rodziny, regionu i narodu, obywatelstwa i politycznej reprezentatywności (ale też wykluczenia) $^{30}$.

Należy zaznaczyć, że artyści aktywni w Serbii maksymalnie wykorzystują immanentną teatralność traumy. Ustanawiają oni sukcesywnie nowe prawa jej (roz)poznania i wytwarzają alternatywną wiedzę o doświadczeniach poznających podmiotów oraz teorii dotyczących tożsamości w obliczu zagrożenia. Co więcej, trauma w tekście o potencjale performatywnym oraz możliwość jej odgrywania mogą stanowić nawiązanie do praktyk terapeutycznych, a nawet pewien ich wariant. Założenia takich aktów artystycznych pokrywają się bowiem z bazowymi celami psycho- lub socjodramy oraz wywodzącej się z nich teatroterapii ${ }^{31}$. Należy podkreślić, że teatr jest medium cenionym wśród twórców zaangażowanych, lecz także wśród terapeutów i pacjentów ze względu na dokonującą się w nim syntezę sztuk, która pozwala jednocześnie na nakładanie się różnych form aktywności artystycznej oraz intensyfikację oddziaływań służących korekcji zaburzeń i pozytywnej modyfikacji. Sceniczna rekonstrukcja traumy pozwala nie tylko na ujawnienie stanów emocjonalnych oraz przeżycie katharsis, ale też na zmniejszenie wewnętrznej kontroli i mocy generującej oraz umacniającej apatię.

28 J. Brągiel, Zrozumieć dziecko skrzywdzone, Opole 1996, s. 80.

29 T. Łysak, op. cit., s. 13.

30 L. Gilmore, op. cit., s. 371.

31 Klasyczne zastosowanie tych metod opiera się na aktywnej technice wchodzenia w rolę, autoprezentacji, uzewnętrzniania konfliktów, przekształcania ich w symboliczne formy odgrywanego przedstawienia. Spektakl teatralny, w zależności od swojej formuły i charakteru, może być wykorzystywany w ukierunkowanym (aktywizującym) lub nieukierunkowanym (receptywnym) leczeniu traumy. 
Najbardziej optymistycznie nastraja jednak założenie i dążenie autorów, żeby motyw traumy, percypowany i przetwarzany z narzuconą niekonwencjonalną optyką (w tym wypadku dziecięcą), uwrażliwiającą na genezę aktualnych problemów socjopolitycznych, stał się rodzajem pomostu między kulturami, współtworzył kulturowe narzędzie opisu umożliwiające przekroczenie granic polityczno-geograficznych, a może też generacyjnych ${ }^{32}$. Tego rodzaju ujęcie, niewykluczone, że zawężone, zbyt lokalne i hermetyczne, stwarza szanse na zrozumienie cierpienia przedstawicieli kultur niezachodnich i mniejszościowych. Być może właśnie dzięki temu opracowania artystyczne traumy będą odznaczać się większą inkluzywnością i wrażliwością na różnice kulturowe ${ }^{33}$.

\section{Bibliografia}

Brągiel J., Zrozumieć dziecko skrzywdzone, Wydawnictwo Uniwersytetu Opolskiego, Opole 1996.

Craps S., Poza eurocentryzm. Teoria traumy w epoce globalizacji, tłum. J. Burzyński, [w:] Antologia studiów nad traumą, red. T. Łysak, Universitas, Kraków 2015, s. 417-442.

Długosz P., Strategie radzenia sobie z trauma przemian na Podkarpaciu, [w:] Oblicza europejskiego pluralizmu, red. Z. Drozdowicz, Fundacja Humaniora, Poznań 2003, s. 201-213.

Gilmore L., Przypadki graniczne: trauma, autoprezentacja i prawne formy tożsamości, tłum. J. Burzyński, [w:] Antologia studiów nad traumą, red. T. Łysak, Universitas, Kraków 2015, s. 359-376.

Govedić N., Trauma apatije: dvije dramatičarske postjugoslavenske Nigdine (Ivana Sajko i Biljana. Srbljanović), [w:] Dramski tekst danas u Bosni i Hercegovini, Hrvatskoj, Srbiji i Crnoj Gori (Međunarodni simpozijum univerzitetskih predavača, teatrologa i pozorišnih kritičara), red. S. Anđelković, Disput, Novi Sad 2004, s. 152-166.

Hartman G.H., Wiedza traumatyczna i badania literackie, tłum. J. Burzyński, [w:] Antologia studiów nad trauma, red. T. Łysak, Universitas, Kraków 2015, s. 377-416.

Kwarta P., Potraumatyczny rozwój u dzieci i młodzieży - perspektywy badawcze, „Postępy psychologii i psychiatrii" 21, 2012, s. 293-297.

Lazin M., Otkud uspeh Biljane Srbljanović?, [w:] Dramski tekst danas u Bosni i Hercegovini, Hrvatskoj, Srbiji i Crnoj Gori (Međunarodni simpozijum univerzitetskih predavača, teatrologa i pozorišnih kritičara), red. S. Anđelković, Disput, Novi Sad 2004, s. 167-181.

Lowenstein A., Moment alegoryczny, tłum. J. Burzyński, [w:] Antologia studiów nad traumą, red. T. Łysak, Universitas, Kraków 2015, s. 285-312.

Lukić D., Drama ratne traume, Meandarmedia, Zagreb 2009.

Łysak T., Trauma - od genealogii pojęcia do studiów nad trauma, [w:] Antologia studiów nad traumą, red. T. Łysak, Universitas, Kraków 2015, s. 5-30.

Marković M., Maja i ja i Maja, 9 września 2016, https://docs.google.com/document/d/1LFtYf4rqtBl-hRNGGZrGtPn1Rd86bB1MGK8TkQzM3GU/edit.

Nikolić D., Deca autizma ili Male priče o malim ljudima, [w:] Dramski tekst danas u Bosni i Hercegovini, Hrvatskoj, Srbiji i Crnoj Gori (Međunarodni simpozijum univerzitetskih predavača, teatrologa i pozorišnih kritičara), red. S. Anđelković, Disput, Novi Sad 2004, s. 141-151.

Seltzer M., Kultura rany, tłum. A. Rejniak-Majewska, [w:] Antologia studiów nad traumą, red. T. Łysak, Universitas, Kraków 2015, s. 313-358.

32 T. Łysak, op. cit., s. 23.

33 S. Craps, op. cit., s. 428.

Miscellanea Posttotalitariana Wratislaviensia 6/2017

(C) for this edition by CNS 
Šljivar T., Grebanje ili Kako se ubila moja baka, [w:] Biseri iz upravničkih fioka, red. S. Bodrož, Parobrod, Beograd 2013, s. 295-312.

Srbljanović B., Pad - Beogradska trilogija - Porodične priče, Otkrovenje, Beograd 2000.

Srbljanović B., Sytuacje rodzinne, tłum. D.J. Ćirlić, „Dialog” 5, 1999, s. 38-69.

Vujošević F., Riječ dramaturga, 9 września 2016, http://www.bnp.ba/bnp/predstave/velika-scena/grebanje.

Przyjęto do druku/Accepted for publication: 5.03.2017 